\title{
TINGKAT KEPATUHAN PELAKSANAAN TATA KELOLA BPR SETELAH DIBERLAKUKANNYA PERATURAN OJK TENTANG PENERAPAN TATA KELOLA BPR DI WILAYAH KERJA KANTOR OJK MALANG
}

Submitted Date :

27 Februari 2019

Accepted Date :

12 Maret 2019
Dian Wijayanti

Fakultas Ekonomi dan Bisnis Universitas Ma Chung dian.wijayanti@machung.ac.id

Tommy M. H. Hutapea

Fakultas Ekonomi dan Bisnis Universitas Ma Chung tommy.hutapea@machung.ac.id

\section{Suggested Citation:}

Priambodo, R. dan Supriyatno, E. 2007. Penerapan Good Corporate Governance sebagai Landasan Kinerja Perbankan, Usahawan No.05 Th XXXVI Hal. 22-30, Jakarta.

\section{Abstrak}

Penelitian deskriptif ini bertujuan untuk melihat tingkat kepatuhan BPR dengan membuat gambaran secara sistematis, faktual dan akurat mengenai fakta-fakta, sifat-sifat serta hubungan antara fenomena yang diselidiki. Jenis data yang digunakan adalah data kuantitatif dengan teknik pengumpulan data menggunakan penyebaran kuesioner kepada Direktur dan atau Pejabat yang mewakili BPR. Hasil Penelitian menunjukkan bahwa Direktur BPR di Wilayah Kerja Kantor OJK Malang sebanyak 67,80\% (di bawah $81 \%$ kriteria Patuh) telah memenuhi kriteria patuh dalam penerapan peraturan yang diberlakukan. Agar tingkat kepatuhan BPR semakin baik, disarankan untuk memenuhi kelengkapan organisasi khususnya penerapan fungsi auditor internal dan manajemen risiko serta pelaksanaan tugas-tugas Direksi dan Dewan Komisaris BPR.

Keywords: Kapatuhan, Tata Kelola BPR, Peraturan OJK, BPR Wilayah Kerja OJK Malang

\section{Abstract}

This descriptive study aims to look at the level of compliance of the BPR by making a systematic, factual and accurate description of the facts, characteristics and relationships between the phenomena investigated. The type of data used is quantitative data with data collection techniques using questionnaires to the Director and / or Officer representing the BPR. The results of the study indicate that the Director of BPR in the Work Area of the OJK Malang Office as much as $67.80 \%$ (below $81 \%$ of the compliant criteria) has met the criteria of compliance in the application of the regulations that are in force. In order to improve the level of BPR compliance, it is recommended to fulfill the organization's requirements, especially the implementation of the functions of internal auditors and risk management and the implementation of the duties of the BPR's Board of Directors and Board of Commissioners.

Keywords : Compliace, BPR Governance, OJK Regulations, BPR in Work Area OJK Malang 


\section{Pendahuluan}

Perekonomian Indonesia yang senantiasa bertumpu pada usaha mikro, kecil dan menengah (UMKM) merupakan salah satu dasar penetapan strategi pemerintah dalam rangka pemulihan ekonomi nasional yaitu pembangunan yang terfokus pada pemberdayaan UMKM. Sejalan dengan strategi pemerintah tersebut, BPR sebagai salah satu jenis bank yang selama ini telah memberikan pelayanan perbankan terutama kepada usaha mikro dan kecil (UMK) juga terus mengalami perkembangan. Perkembangan industri BPR yang terus meningkat diikuti dengan persaingan yang semakin tajam serta dukungan dari sarana teknologi informasi yang tumbuh sangat deras justru mengakibatan semakin tingginya risiko yang dihadapi oleh manajemen BPR.

Risiko yang dihadapi oleh BPR bukan hanya risiko kredit, risiko bunga, risiko likuiditas, tetapi juga risiko operasional, dan risiko hukum sebagai akibat ketidakpatuhan terhadap sistem dan peraturan yang berlaku baik peraturan yang dibuat oleh pihak internal maupun pihak ekternal yang pada akhirnya dapat berdampak pada risiko reputasi. Risiko yang timbul di dunia bisnis khususnya di industri perbankan adalah masalah keagenan yang merupakan konflik kepentingan antara pemegang saham dan manajer yang asimetris, disamping adanya tuntutan perusahaan dan individu yang menyebabkan sering terjadinya kecurangan atau fraud dalam operasionalnya.

Pemerintah sangat berkepentingan atas hadirnya BPR karena posisi BPR yang strategis tersebut perlu dipertahankan dan ditingkatkan agar keberadaan BPR dapat memberikan manfaat yang lebih besar bagi masyarakat dan mendorong perekonomian daerah. Pemerintah dalam hal ini Otoritas Jasa Keuangan (OJK) secara konsisten terus mengatur dan mengawasi perkembangan sektor keuangan khususnya industri BPR sebagai perannya dalam unsur Stabilitas Sistem Keuangan Indonesia. Salah satu peraturan yang dikeluarkan oleh OJK adalah Peraturan OJK Nomor 4/POJK.03/2015 tentang Penerapan Tata Kelola Bagi Bank Perkreditan Rakyat yang dikeluarkan pada bulan Maret 2015 dengan masa penyesuaiannya sampai akhir tahun 2017. Peraturan ini dikeluarkan dengan mempertimbangkan bahwa semakin besar volume usaha BPR dan dalam menghadapi tantangan serta persaingan yang semakin berat, maka BPR perlu melengkapi diri dengan sistem dan prosedur operasional yang baku. Kelengkapan manajemen dalam mengelola BPR yang baik wajib memiliki Pedoman Tata Kelola BPR untuk meminimalkan risiko tersebut di atas. Tata kelola (Corporat Governance) terdiri atas 5 prinsip yang menjadi dasar manajemen untuk mencapai tujuan BPR yaitu, transparansi, akuntabilitas, responsibilitas, independensi dan kewajaran.

Menurut Sutedi (2011), mekanisme Good Corporate Governance (GCG) diarahkan untuk menjamin dan mengawasi berjalannya sistem governance dalam sebuah organisasi. Sedangkan mekanisme Corporate Governance (CG) menurut Priambodo dan Supriyatno (2007) adalah suatu sistem yang mampu mengendalikan dan mengarahkan kegiatan operasional perusahaan serta pihak-pihak yang terlibat didalamnya, sehingga dapat digunakan untuk menekan terjadinya masalah keagenan. Disamping itu, penerapan GCG dapat memberikan informasi yang benar, akurat dan tepat waktu. Mekanisme corporate governance (CG) sebagai upaya penegakan praktik CG dalam perusahaan diharapkan dapat mengurangi konflik keagenan dan juga diharapkan mampu untuk mengontrol biaya.

Pada dasarnya seluruh organisasi atau perusahaan akan mengelola usaha bisnisnya secara baik agar tujuannya dapat tercapai dengan mengorbankan sumber daya seminimal mungkin tetapi memperoleh manfaat dan keuntungan yang sebesar-besarnya. Begitu halnya dengan BPR, sebelum diberlakukannya POJK Nomor 4/POJK.03/2015 Tentang Penerapan Tata Kelola Bagi Bank Perkreditan Rakyat, secara alamiah akan mengelola bisnisnya dengan niat baik untuk menjaga kepentingan stakeholder. Sehubungan dengan hal tersebut di atas, pada pertengahan tahun 2016 peneliti telah melakukan penelitian terhadap 37 BPR yang cukup mewakili seluruh BPR yang berada di wilayah kerja OJK Malang, guna mengamati sejauh mana perhatian dan kesiapan para Direktur BPR dalam menyikapi dan mematuhi POJK tersebut dengan memilih topik "KEEFEKTIFAN PENERAPAN PRINSIP-PRINSIP TATA KELOLA BANK PERKREDITAN RAKYAT DI WILAYAH KERJA KANTOR OJK MALANG."

Hasil penelitian tersebut, memberikan gambaran bahwa kalkulasi yang diperoleh adalah 16 responden memperoleh nilai rata-rata sebesar 86,30 dengan predikat Efektif, 20 responden memperoleh nilai rata-rata 
sebesar 71,75 dengan predikat Cukup Efektif dan 1 responden memperoleh nilai sebesar 60,00 berada di skala Kurang Efektif. Secara keseluruhan 37 responden memperoleh nilai sebesar 77,45 dengan predikat Cukup Efektif.

Memperhatikan hasil akhir bahwa Direksi 37 BPR tersebut masih Cukup Efektif dalam menyikapi POJK Nomor 4/POJK.03/2015 dan atas hasil kalkulasi terhadap prinsip-prinsip tata kelola di atas, maka dengan telah berakhirnya masa penyesuaian penerapan tata kelola bagi BPR pada akhir 2017, peneliti ingin meneliti sejauh mana Direksi BPR mematuhi POJK dimaksud dengan judul "Tingkat Kepatuhan Pelaksanaan Tata Kelola Bpr Setelah Diberlakukannya Peraturan Ojk Tentang Penerapan Tata Kelola Bpr Di Wilayah Kerja Kantor Ojk Malang".

\section{Kajian Teori}

Corporate Governance merupakan rangkaian proses terstruktur yang digunakan untuk mengelola serta mengarahkan atau memimpin bisnis dan usaha-usaha korporasi dengan tujuan untuk meningkatkan nilai-nilai perusahaan serta kontinuitas usaha. Terdapat beberapa pemahaman tentang pengertian Corporate Governance yang dikeluarkan beberapa pihak baik dalam perspektif yang sempit (shareholder) dan perspektif yang luas (stakeholders), namun pada umumnya menuju suatu maksud dan pengertian yang sama.

Menurut Peraturan Bank Indonesia No. 8/4/PBI/2006 tentang Pelaksanaan Good Corporate Governance Bagi Bank Umum, Good Corporate Governance adalah suatu tata kelola bank yang menerapkan prinsip-prinsip keterbukaan (transparency), akuntabilitas (akuntabilitas), pertanggungjawaban (responsibilitas), independensi (Independency), dan kewajaran (kewajaran).

Pelaksanaan GCG yang baik merupakan langkah penting dalam membangun kepercayaan pasar dan mendorong arus investasi internasional yang lebih stabil dan bersifat jangka panjang. Menurut Bassel Committee on Banking Supervision, tujuan dan manfaat GCG antara lain sebagai berikut:

a. Mengurangi agency cost, biaya yang timbul karena penyalahgunaan wewenang, ataupun berupa biaya pengawasan yang timbul untuk mencegah timbulnya suatu masalah

b. Mengurangi biaya modal yang timbul dari manajemen yang baik, yang mampu meminimalkan risiko.

c. Memaksimalkan nilai saham perusahaan, sehingga dapat meningkatkan citra perusahaan di mata publik dalam jangka panjang

d. Mendorong pengelolaan perbankan secara profesional, transparan, efisien serta memberdayakan fungsi dan meningkatkan kemandirian dewan komisaris, Direksi dan RUPS (Rapat Umum Pemegang Saham)

e. Mendorong dewan komisaris, anggota direksi, pemegang saham dalam membuat keputusan dan menjalankan tindakan dilandasi moral yang tinggi dan kepatuhan terhadap perundang-undangan yang berlaku.

f. Menjaga going concern (keberlangsungan usaha) perusahaan

Hery (2013:4-5) mengatakan bahwa, ada lima kriteria GCG versi The Organization for Economic Cooperation and Development (OECD), yaitu sebagai berikut:

1. The rights of shareholders

Hak para pemegang saham terdiri dari hak untuk menerima informasi yang relevan mengenai perusahaan pada waktu yang tepat, mempunyai peluang untuk ikut berpartisipasi dalam setiap pengambilan keputusan termasuk hak dalam pembagian keuntungan/ laba perusahaan. Pengendalian terhadap perusahaan haruslah dilakukan scara efisien dan setransparan mungkin.

2. The equitable treatment of shareholders

Adanya perlakuan yang adil terhadap seluruh pemegang saham, khususnya para pemegang saham minoritas atau asing, yang terdiri atas hak atas pengungkapan yang lengkap mengenai segala informasi perusahaan yang material. Seluruh pemegang saham dengan kelas saham yang sama harus 
diperlakukan secara adil. Anggota corporate board dan manajer diharuskan mengungkapkan segala kepentingannya yang material atas setiap transaksi perusahaan yang terjadi.

3. The role of stakeholders in corporate governance

Peran pihak-pihak yang berkepentingan terhadap perusahaan haruslah diakui melalui penetapan secara hukum. Kerangka kerja GCG harus dapat mendorong kerja sama yang aktif antara pihak perusahaan dengan stakeholder demi menciptakan pekerjaan, kemakmuran, dan perusahaan yang sehat secara finansial.

4. Disclosure and transparency

Adanya pengungkapan dan transparansi yang akurat dan tepat waktu atas segala hal yang material terhadap kinerja perusahaan, kepemilikan dan tata kelola perusahaan, serta masalah lain yang berkaitan dengan karyawan dan stakeholder. Laporan keuangan haruslah diaudit oleh pihak yang independen dan disajikan berdasarkan standar kualitas tertinggi.

5. The responsibilities of the board

Kerangka kerja GCG harus menjamin adanya arahan, bimbingan dan pengaturan yang strategis atas jalannya operasional maupun finansial perusahaan, pemantauan dan pengawasan yang efektif oleh corporate board, dan adanya pertanggungjawaban corporate board kepada perusahaan dan pemegang saham.

Hasil penelitian terdahulu mengungkapkan bahwa a peranan penting antara prinsip-prinsip GCG yang ada pada perusahaan, dimana dengan penerapan prinsip GCG maka diyakini akan menolong perusahaan secara umum dan perekonomian negara secara khususnya. Selain itu hasil penelitian ini memperlihatkan bahwa motivasi perusahaan adalah untuk melaksanakan prinsip GCG secara utuh, memenuhi harapan stakeholder, mendapatkan legitimasi, dan memenangkan penghargaan tertentu (Tadikapury, 2011). Pasorong (2012) menunjukkan adanya peranan penting antara penerepan GCG terhadap prosedur pemberian kredit. Hasil penelitian ini mendorong dan memotivasi perusahaan agar prinsip GCG dijadikan sebagai budaya perusahaan. Dan Labesi (2013) mengisyaratkan bahwa pelaksanaan GCG dan penerapan prinsip-prinsipnya di PT Bank Sulut Kantor Pusat Manado telah terwujud dengan baik. Pengawasan terhadap kinerja manajemen terkontrol dengan baik dan tujuan perusahaan untuk mengarahkan perusahaan pada peningkatan nilai perusahaan dijalankan dengan baik.

Penelitian ini mempertimbangkan Peraturan Otoritas Jasa Keuangan (POJK) NOMOR 4/POJK.03/2015 TENTANG PENERAPAN TATA KELOLA BAGI BANK PERKREDITAN RAKYAT yang masa penyesuaiannya akan berakhir pada akhir Desember 2017. Penelitian terdahulu melihat seberapa jauh Direksi BPR mempersiapan diri untuk melengkapi atribut tata kelola BPR sebelum POJK tersebut diberlakukan. Setelah diberlakukannya POJK tersebut di atas, diharapkan para jajaran pimpinan Bank Perkreditan Rakyat di wilayah kerja Kantor OJK Malang dapat menyesuaikan atau meningkatkan bahkan mengembangkan tata kelola organisasinya ke arah yang lebih baik. Dengan adanya tata kelola yang baik, kinerja BPR juga dapat terdongkrak, sehingga dapat bermanfaat bagi perkembangan ekonomi di sektor perbankan.

\section{Metode Penelitian}

Lokasi penelitian ini berada di Kota Malang. Peneliti bekerja sama dengan Otoritas Jasa Keuangan (OJK) Malang mengundang Direktur Bank Perkreditan Rakyat (BPR) se wilayah kerja Kantor OJK Malang ke Universitas Ma Chung dalam rangka penjelasan maksud, tahapan, dan pengambilan data penelitian. Subyek penelitian yang akan dimintai keterangan melalui kuesioner adalah Direktur BPR di Kota Malang yang berjumlah kurang lebih 40 direktur.

Jenis penelitian ini adalah penelitian deskriptif yakni penelitian yang bertujuan untuk membuat deskripsi, gambaran atau lukisan secara sistematis, faktual dan akurat mengenai fakta-fakta, sifat-sifat serta hubungan antara fenomena yang diselidiki. Jenis data yang digunakan dalam penelitian ini adalah data kuantitatif. Teknik pengumpulan data adalah dengan cara penyebaran kuesioner kepada 40 Direktur BPR di Wilayah Kerja Kantor OJK Malang yang memiliki total aset minimal Rp10 milyar. 
Populasi dalam penelitian ini adalah seluruh Direktur BPR di Wilayah Kerja Kantor OJK Malang. Jumlah BPR di Wilayah Kerja Kantor OJK Malang berjumlah 86 BPR. Dalam hal ini, peneliti akan menguji Tingkat Kepatuhan Penerapan Tata Kelola BPR terhadap seluruh BPR yang berada di Wilayah Kerja Kantor OJK Malang, apakah telah menerapkan prinsip-prinsip Tata Kelola BPR atau sebaliknya. Tingkat kepatuhan penerapan Tata Kelola BPR ini diukur dengan menggunakan indikator-indikator yang tertuang dalam daftar pertanyaan kuesioner. Indikatornya adalah Prinsip-prinsip:

1. Pelaksanaan Tugas dan Tanggung Jawab Direksi

2. Pelaksanaan Tugas dan Tanggung Jawab Dewan Komisaris

3. Penanganan Benturan Kepentingan

4. Penerapan Fungsi Kepatuhan

5. Penerapan Fungsi Audit Intern

6. Penerapan Fungsi Audit Ekstern

7. Penerapan Manajemen Risiko, Termasuk Sistem Pengendalian Intern

8. Batas Maksimum Pemberian Kredit

9. Rencana Bisnis BPR

10. Transparansi Kondisi Keuangan dan Non Keuangan

Indikator Kelengkapan dan Pelaksanaan Tugas atau Fungsi Komite (bagi BPR yang memiliki Modal Inti paling sedikit Rp80 milyar) tidak dihitung/dinilai karena di wilayah Kerja OJK Malang belum ada BPR yang memiliki Modal Inti paling sedikit RP80 milyar.

Tabel 1 Indikator dan Skala Pengukuran

\begin{tabular}{|c|c|c|c|}
\hline VARIABEL & INDIKATOR & SKALA PENGUKURAN & INSTRUMEN \\
\hline $\begin{array}{l}\text { Perwujudan Tata } \\
\text { Kelola BPR }\end{array}$ & $\begin{array}{ll}\text { 1. } & \text { Pelaksanaan Tugas dan Tanggung } \\
\text { 2. } & \text { Pawab Direksi } \\
\text { 3. Jaksanaan Tugas dan Tanggung } \\
\text { 3. Penanganan Kenturan Kepentingan } \\
\text { 4. Penerapan Fungsi Kepatuhan } \\
\text { 5. Penerapan Fungsi Audit Intern } \\
\text { 6. Penerapan Fungsi Audit Ekstern } \\
\text { 7. Penerapan Manajemen Risiko, } \\
& \text { Termasuk Sistem Pengendalian } \\
\text { 8. } & \text { Batern Maksimum Pemberian Kredit } \\
\text { 9. } & \text { Rencana Bisnis BPR } \\
\text { 10. Transparansi Kondisi Keuangan dan } \\
\end{array}$ & Ordinal & Kuesioner \\
\hline
\end{tabular}

Pengumpulan data dilakukan dengan metode survey kepada responden. Peneliti menyebarkan kuesioner kepada Direktur BPR di Wilayah Kerja Kantor OJK Malang. Penyebaran kuesioner dilakukan melalui kolaborasi dengan OJK Malang. Dalam penelitian ini digunakan skala Likert 4 poin, yaitu skor 4 untuk pilihan "PATUH", skor 3 untuk pilihan "CUKUP PATUH", skor 2 untuk pilihan "BELUM PATUH", skor 1 untuk pilihan "TIDAK PATUH".

Analisis data dilaksanakan dengan membandingkan kondisi yang sebenarnya di BPR dengan kriteriakriteria yang telah ditetapkan. Data kemudian dianalisis untuk menjawab tingkat kepatuhan penerapan Tata Kelola BPR berdasarkan hasil kuesioner dengan menggunakan perhitungan persentase. Berikut adalah tahapan analisis data yang akan dilakukan.

a. Tabulasi: mengelompokkan data yang diteliti kemudian disusun secara teratur dan selanjutnya dibuat dalam bentuk tabel. 
b. Pemrosesan data: data yang telah ditabulasi kemudian diolah atau diproses dalam bentuk matematis dengan menggunakan model analisis yang telah ditentukan.

c. Interpretasi data: data yang telah diproses dalam bentuk matematis akan dianalisis selanjutnya ditarik suatu kesimpulan. Metode analisis yang digunakan dalam penelitian ini adalah deskriptif berdasarkan persentase jawaban responden terhadap masing-masing pernyataan dalam kuesioner yang dirumuskan sebagai berikut:

$$
\begin{aligned}
& P=K / N(\%) \\
& \text { Keterangan: }
\end{aligned}
$$

P : presentase yang dihasilkan

$\mathrm{K} \quad$ : jumlah skor Kepatuhan yang diperoleh dari responden

$\mathrm{N} \quad$ : jumlah pertanyaan Kepatuhan

Selanjutnya untuk mengukur tingkat kepatuhan Tata Kelola (GCG) menurut Riduwan (2005), yakni dengan skala interval sebagai berikut :

$$
\begin{array}{ll}
81-100 & =\text { Patuh } \\
61-80 & =\text { Cukup Patuh } \\
41-60 & =\text { Belum Patuh } \\
21-40 & =\text { Tidak Patuh }
\end{array}
$$

\section{Hasil dan Pembahasan}

Data Penelitian diperoleh dengan metode survey kepada responden yaitu direktur BPR di Wilayah Kerja OJK Malang. Survey dilakukan saat pelaksanaan pertemuan dengan BPR se Wilayah Kerja OJK Malang pada tanggal 4 Oktober 2018. Kuesioner dibagikan kepada 74 responden yang hadir dan kuesioner yang kembali berjumlah 59 . Dengan demikian response rate survey ini adalah sebesar $79,7 \%$.

Deskripsi responden adalah sebagai berikut, 59 responden menduduki jabatan direktur/direktur utama, 1 responden menduduki jabatan kepala bagian kepatuhan/PE. Klasifikasi responden yang menjawab kuesioner adalah sebagai berikut:

Tabel 2. Deskripsi Responden

\begin{tabular}{clc}
\hline No. & \multicolumn{1}{c}{ Deskripsi } & Jumlah \\
\hline 1 & Peserta yang mencantumkan nama BPR dan menjawab pertanyaan & 44 BPR \\
2 & Peserta yang tidak mencantumkan nama BPR tetapi memberi jawaban & 7 BPR \\
3 & Peserta yang tidak mencantumkan nama BPR dan tidak memberi jawaban & 2 BPR \\
4 & Peserta yang mencantumkan nama BPR tetapi tidak memberi jawaban & 6 BPR \\
\hline
\end{tabular}

Sumber : Data dioleh, 2018

Penelitian ini bertujuan untuk meneliti sejauh mana BPR telah mematuhi POJK Nomor 4/POJK.03/2015 Tentang Penerapan Tata Kelola Bagi Bank Perkreditan Rakyat. Pengujian dilakukan dengan membandingkan jawaban setiap responden dengan jumlah keseluruhan pertanyaan kuesioner. Secara keseluruhan perhitungan tabulasi data menunjukkan hasil sebagai berikut:

Tabel 3. Hasil Tabulasi Data

\begin{tabular}{ccc}
\hline Jumlah Responden & Persentase & Kriteria \\
\hline 40 Responden & $67,80 \%$ & Patuh \\
7 Responden & $11,86 \%$ & Cukup Patuh \\
3 Responden & $5.08 \%$ & Kurang Patuh \\
1 Responden & $1,69 \%$ & Tidak Patuh \\
8 Responden & $13.56 \%$ & Tidak memberi jawaban \\
\hline
\end{tabular}

Sumber : Data diolah, 2018 
Analisis tambahan dilakukan untuk melihat tingkat kepatuhan BPR paling banyak di aspek yang mana.

Tabel 4. Presentase Skor Masing-Masing Indikator

\begin{tabular}{rrrrrrrrrrr}
\hline \multirow{2}{*}{ Skor } & \multicolumn{10}{c}{ Indikator } \\
\cline { 2 - 11 } & \multicolumn{1}{c}{1} & \multicolumn{1}{c}{3} & \multicolumn{1}{c}{4} & \multicolumn{1}{c}{5} & \multicolumn{1}{c}{6} & \multicolumn{1}{c}{7} & \multicolumn{1}{c}{8} & 9 & \multicolumn{1}{c}{10} \\
\hline 1 & $2.06 \%$ & $1.85 \%$ & $8.50 \%$ & $8.60 \%$ & $8.26 \%$ & $2.35 \%$ & $3.59 \%$ & $0.39 \%$ & $0.00 \%$ & $0.00 \%$ \\
2 & $2.17 \%$ & $2.42 \%$ & $7.19 \%$ & $4.07 \%$ & $7.56 \%$ & $1.57 \%$ & $7.68 \%$ & $3.92 \%$ & $1.96 \%$ & $0.84 \%$ \\
3 & $13.62 \%$ & $12.57 \%$ & $18.95 \%$ & $21.87 \%$ & $15.83 \%$ & $5.10 \%$ & $26.31 \%$ & $8.24 \%$ & $6.54 \%$ & $6.44 \%$ \\
4 & $81.63 \%$ & $81.66 \%$ & $64.05 \%$ & $61.99 \%$ & $48.60 \%$ & $61.57 \%$ & $57.19 \%$ & $83.53 \%$ & $90.20 \%$ & $92.44 \%$ \\
0 & $0.52 \%$ & $1.50 \%$ & $1.31 \%$ & $3.47 \%$ & $19.75 \%$ & $29.41 \%$ & $5.23 \%$ & $3.92 \%$ & $1.31 \%$ & $0.28 \%$ \\
& $100 \%$ & $100 \%$ & $100 \%$ & $100 \%$ & $100 \%$ & $100 \%$ & $100 \%$ & $100 \%$ & $100 \%$ & $100 \%$ \\
\hline
\end{tabular}

Sumber : Data diolah, 2018

Berdasarkan Tabel 1.5, kepatuhan ditunjukkan dengan skor 4, dan persentase jawaban responden terbanyak di indicator ke-10 yaitu Transparansi Kondisi Keuangan dan Non Keuangan (92,44\%). Hal ini dapat diintepretasikan bahwa BPR telah patuh dalam pelaksanaan tata kelola terkait dengan fungsi transparansi.

Aspek Tata Kelola yang dinilai belum memenuhi kepatuhan dapat dilihat dari skor yang diberikan adalah 1 . Berdasarkan Tabel 1.5, persentase nilai 1 yang tertinggi adalah di indicator Penerapan Fungsi Kepatuhan (8,6\%). Sedangkan persentase jawaban yang dinilai Kurang Patuh (angka 2) terbanyak di indicator Penerapan Manajemen Risiko $(7,68 \%)$. Berikut tabel yang menunjukkan urutan jawaban terbanyak pada penilaian Tidak Patuh dan Kurang Patuh.

Tabel 5. Ranking Presentase Tidak Patuh

\begin{tabular}{lll}
\hline \multicolumn{1}{c}{ Ranking } & Persentase & \multicolumn{1}{c}{ Indikator } \\
\hline Pertama & $8.6 \%$ & Penerapan Fungsi Kepatuhan \\
Kedua & $8,50 \%$ & Penanganan Benturan Kepentingan \\
Ketiga & $8,26 \%$ & Penerapan Fungsi Audit Intern \\
Keempat & $3,59 \%$ & Penerapan Manajemen Risiko \\
\hline
\end{tabular}

Sumber : Data diolah, 2018

Tabel 6. Ranking Presentase Kurang Patuh

\begin{tabular}{lll}
\hline \multicolumn{1}{c}{ Ranking } & Persentase & \multicolumn{1}{c}{ Indikator } \\
\hline Pertama & $7,68 \%$ & Penerapan Manajemen Risiko \\
Kedua & $7,56 \%$ & Penerapan Fungsi Audit Intern \\
Ketiga & $7,19 \%$ & Penanganan Benturan Kepentingan \\
Keempat & $4,07 \%$ & Penerapan Fungsi Kepatuhan \\
\hline
\end{tabular}

Sumber : Data diolah, 2018

Berdasarkan hasil tersebut maka secara umum BPR di Wilayah Kerja OJK Malang sebagian besar (40 responden dari total 59 responden) telah memenuhi ketentuan kepatuhan terhadap penerapan Tata Kelola BPR yang diatur dalam POJK Nomor 4/POJK.03/2015 Tentang Penerapan Tata Kelola Bagi Bank Perkreditan Rakyat. Sedangkan 19 responden BPR lainnya yang belum lengkap bahkan belum memiliki unit kerja Audit Intern, Kebijakan Fungsi Kepatuhan, Penerapan Manajemen Risiko serta belum patuhnya Dewan Komisaris dalam menjalankan tugas dan fungsinya.

Berdasarkan urutan indikator Tata Kelola yang memiliki persentase Tidak Patuh terbanyak adalah Penerapan Fungsi Kepatuhan. Hal ini tampak dari persentase isian skor 1 di indicator ini adalah terbanyak dibandingkan indicator lainnya. Persentase ini dekat dengan indicator Penangan Benturan Kepentingan dan 
Penerapan Fungsi Audit Intern. Tindak lanjut penelitian, maka disiapkan contoh Kebijakan Audit Intern yang secara umum dapat digunakan oleh BPR sebagai dasar melakukan fungsi pengawasan sebagai langkah awal mematuhi prinsip controlling dalam manajemen. Diharapkan dengan adanya panduan ini BPR dapat juga mengatasi kelemahan dalam penerapan fungsi kepatuhan dan penanganan benturan kepentingan.

\section{Kesimpulan}

Tujuan penelitian ini adalah untuk meneliti sejauh mana BPR telah mematuhi POJK Nomor 4/POJK.03/2015 Tentang Penerapan Tata Kelola Bagi Bank Perkreditan Rakyat. Metode survei dilakukan untuk pengambilan data dengan responden adalah direktur BPR di Wilayah Kerja OJK Malang. Kepatuhan POJK tentang penerapan Tata Kelola BPR diukur dengan menggunakan indicator kepatuhan yang terdiri atas 10 (sepuluh) aspek tata kelola yang telah ditentukan berdasarkan POJK tersebut.

Metode analisis data yang dilakukan adalah dengan menghitung skor masing-masing BPR dan dibandingkan dengan nilai skor sempurna kepatuhan. Hasil yang diperoleh sebanyak $67,80 \%$ responden memiliki skor pada kriteria Patuh. Hal ini dapat disimpulkan bahwa di Wilayah Kerja OJK Malang sebagian besar BPR telah masuk kriteria Patuh dalam hal penerapan Tata Kelola sesuai dengan POJK Nomor 4/POJK.03/2015. Peringkat aspek kepatuhan yang dinilai paling banyak telah dipatuhi BPR adalah Transparansi Kondisi Keuangan dan Non Keuangan dengan jawaban patuh sebanyak 92,44\%. Sedangkan aspek kepatuhan yang dinilai paling tidak dipatuhi adalah Penerapan Fungsi Kepatuhan sebanyak 8,6\% jawaban dengan skor minimal.

Berdasarkan hasil penelitian ini, implikasi penelitian adalah bahwa sebanyak 32,20\% BPR masih tergolong cukup patuh hingga tidak patuh. Sehingga hal ini dapat menjadi dasar pendampingan bagi BPR untuk melihat aspek-aspek tata kelola yang masih harus ditingkatkan. Bagi BPR, hasil penelitian ini diharapkan dapat menjadi masukan bagi BPR untuk meningkatkan kepatuhan dalam penerapan tata kelola BPR. Tindak lanjut penelitian, maka disiapkan contoh Kebijakan Audit Intern yang secara umum dapat digunakan oleh BPR sebagai dasar melakukan fungsi pengawasan sebagai langkah awal mematuhi prinsip controlling dalam manajemen. Diharapkan dengan adanya panduan ini BPR dapat juga mengatasi kelemahan dalam penerapan fungsi kepatuhan dan penanganan benturan kepentingan.

Saran penelitian disampaikan untuk penelitian selanjutnya. Diharapkan penelitian selanjutnya dapat mengembangkan penelitian ini dengan menguji perbedaan persentase peringkat kriteria kepatuhan tata kelola pada tingkat patuh dan tidak patuh. Berdasarkan penelitian ini peringkat kriteria tata kelola yang dinilai paling dipatuhi adalah Transparansi Kondisi Keuangan dan Non Keuangan dan kriteria yang dinilai paling tidak dipatuhi adalah Penerapan Fungsi Kepatuhan. Penelitian selanjutnya dapat menguji apakah persentase dari peringkat tertinggi tersebut berbeda signifikan dibandingkan peringkat selanjutnya.

\section{Daftar Pustaka}

Bank Indonesia, 2006, 'Peraturan Bank Indonesia Nomor 8/4/PBI/2006 Tentang Pelaksanaan Good Corporate Governance Bagi Bank Umum', (www.bi.go.id)

Bank Indonesia, 2006, 'Peraturan Bank Indonesia Nomor 8/14/PBI/2006 Perubahan Peraturan Bank Indonesia Nomor 8/4/PBI/2006 Tentang Pelaksanaan Good Corporate Governance Bagi Bank Umum, (www.bi.go.id)

Hery. 2010. Potret Profesi Audit Internal. Bandung : Alfabeta.

Hery. 2013. Setiap Auditor Harus Baca Buku Ini!. CV. Alfabeta. Bandung.

Keputusan Presiden Republik Indonesia No. 38, Tahun 1988 tentang Bank Perkreditan Rakyat. Diakses 26 Februari 2016.

Labesi, Thereza Michiko. 2013. Analisis Penerapan Prinsip-Prinsip Good Corporate Governance di PT Bank Sulut, Kantor Pusat Manado. Jurnal EMBA. Vol. 1 No. 4 Desember 2013, Hal 1274 - 1283. Unsrat: Manado. 
Pasorong, Andrew. 2012. Evaluasi Penerapan Prinsip-Prinsip Good Corporate Governance terhadap Prosedur Pemberian Kredit pada Lembaga Perbankan (Studi Empiris pada Bank Central Asia (Persero) Tbk). Skripsi. Jurusan Akuntansi Fakultas Ekonomi Univeritas Hasanuddin. Makassar.

Peraturan Otoritas Jasa Keuangan No. 4/POJK.03/2015 tentang Penerapan Tata Kelola bagi Bank Perkreditan Rakyat. Diakses 26 Februari 2016.

Priambodo, R. dan Supriyatno, E. 2007. Penerapan Good Corporate Governance sebagai Landasan Kinerja Perbankan. Usahawan No.05 Th XXXVI Hal. 22-30, Jakarta.

Sutedi, Adrian. 2011. Good Corporate Governance. Jakarta : Sinar Grafika.

Tadikapury, Violetta. 2011. Penerapan Good Corporate Governance Pada PT Bank X Tbk Kanwil X. Skripsi. Jurusan Akuntansi Fakultas Ekonomi Univeritas Hasanuddin. Makasar.

Undang - Undang Republik Indonesia No. 7 Tahun 1992 tentang Perbankan. Diakses 26 Februari 2016. 